\title{
Risk Factors of Anencephaly: A Case-Control Study in Dessie Town, North East Ethiopia
}

\author{
Melese Abebe (D) \\ Mekbeb Afework (D) ${ }^{2}$ \\ Bahru Emamu ${ }^{3}$ \\ Demissie Teshome 4 \\ 'Department of Anatomy, School of \\ Medicine, College of Health Science, \\ Wollo University, Dessie, Ethiopia; \\ ${ }^{2}$ Department of Anatomy, School of \\ Medicine, College of Health Sciences, \\ Addis Ababa University, Addis Ababa, \\ Ethiopia; ${ }^{3}$ Department of Radiology, \\ School of Medicine, College of Medicine \\ and Health Science, Wollo University, \\ Dessie, Ethiopia; ${ }^{4}$ Department of \\ Radiography, Dessie Health Science \\ College, Dessie, Ethiopia
}

\begin{abstract}
Introduction: Anencephaly is a form of neural tube defect, which develops when the cranial neuropore is unable to close. It is one of the fatal anomalies of the neural tube. Although most of the causes of anencephaly are unknown, multiple risk factors are associated with this defect. Therefore, this study aimed to investigate the incidence and associated risk factors of anencephaly in Dessie town, in the north eastern region of Ethiopia.

Methods: An institution-based unmatched case-control study was conducted. Sociodemographic characteristics of pregnant women were collected with a structured questionnaire and clinical data were recorded during an ultrasound examination. Data were entered into Epi Info 7 and analyzed by SPSS version 20. Binary logistic regression was applied to detect the associations between risk factors and the occurrence of anencephaly.

Results: The incidence of anencephaly was 3.3/1000 pregnancies. The multivariate logistic regression model indicated that maternal age between 26 and 30 years and khat chewing during pregnancy were significantly associated with anencephaly (OR 0.13 , 95\% CI 0.02 $0.97, p=0.046$; and OR $3.571,95 \%$ CI $1.06-12.06, p=0.04$, respectively). Exposure to typhus and typhoid and the use of antihypertensive drugs during early pregnancy were also significantly correlated as anencephaly risk factors. Furthermore, spina bifida simultaneously occurred with anencephaly significantly $(p<0.05)$.
\end{abstract}

Conclusion: It is suggested that exposure to risk factors such as khat chewing during pregnancy may predispose to the development of anencephaly.

Keywords: anencephaly, neural tube defects, ultrasound, khat chewing

\section{Introduction}

Anencephaly is a form of neural tube defect (NTD), which develops when the cranial neuropore is unable to close during the fourth week of human development. It results in the failure of the major part of the brain to develop, failure of the lamina terminalis to form and a defective bony cranial vault. ${ }^{1}$

Anencephaly cannot be treated; therefore, it is considered a fatal form of NTD. Although most anencephalic babies are stillborn, some of them are born alive, with a small, undeveloped brain which lacks a functioning cerebrum. Anencephalic babies fail to become conscious and do not respond to pain. However, their brainstem may respond to some reflexes, such as breathing, sound and touch. ${ }^{2}$

The exact causes of anencephaly are not known. However, the interaction of genetic and environmental factors is considered to be implicated. Some of its causes, such as genes which provide instructions for making a protein involved in processing the vitamin folate, have been identified. ${ }^{3}$ In the reviews by Pulikkunnel and Thomas and Finnell et al, on the pathogenesis of NTDs and the association of
Correspondence: Melese Abebe Department of Anatomy, School of Medicine, College of Health Science, Wollo University, Dessie, Ethiopia

Email melese19@yahoo.com 
NTDs with folate metabolism, several gene problems that affect enzymes and proteins involved in the transport and metabolism of folate were shown to be associated with NTDs. ${ }^{4,5}$ On the other hand, proprotein convertase subtilisin/kexin type 9 (PCSK9) may have a role in the etiopathogenesis of open NTDs at the critical stages of fetal neuronal differentiation and development. Although it has limitations, PCSK9 may be used as an additional biomarker for the screening of NTDs. ${ }^{6}$

Several studies have reported various risk factors linked to anencephaly, which include socioeconomic status, parental education, maternal age and occupation, smoking, alcoholism, maternal reproductive history, infection during early pregnancy, diabetes, obesity, and maternal use of caffeine and medications during early pregnancy. ${ }^{7-9}$

The prevalence of anencephaly shows great variation among different countries, with 12 per 10,000 births in Iran, ${ }^{10} 10.4$ per 10,000 births in China, $0.00-7.42$ per 10,000 births in Rijeka, Croatia, ${ }^{11} 0.5-0.6$ per 1000 live births in Singapore ${ }^{12}$ and $0.5-6.5$ per 1000 live births in India. ${ }^{13,14}$ However, only a limited amount of research ${ }^{15,16}$ has been conducted in Ethiopia. Therefore, the aim of this study was to investigate the incidence of anencephaly and its associated risk factors in Dessie town, in the north eastern region of Ethiopia.

\section{Subjects and Methods}

\section{Study Design, Study Area, Sample Size and Sampling Method}

This institution-based unmatched case-control study was conducted in the Ethiopian Family Guidance Association (EFGA) North East Model Clinics, Dessie town. The sample size was determined using Epi Info version 7, considering the following assumptions: percentage of control exposed (family history of congenital anomaly) $2 \%$, odds ratio of $8.6,{ }^{17} 95 \%$ confidence interval, $80 \%$ power and a case-to-control ratio of 1:2. The final sample size was 126 (42 cases and 84 controls).

The data were prospectively collected for one year (February 2019 to January 2020). During the study period, 12,713 pregnant women visited the ultrasound center of EFGA Clinics. For every case of anencephaly diagnosed by ultrasound, two women with non-anencephalic fetuses, next to the case, in the same ultrasound center, were assessed as controls. Data for the controls were recorded using the same data sheet used for the cases.

\section{Data Collection Tools and Techniques}

The data were collected with a precoded and pretested structured questionnaire. All recruited women were interviewed, regarding their maternal age, area of residence, number of pregnancies, presence of any chronic disease during pregnancy, number of gestations, infection during gestation, self or family history of anencephaly, and maternal alcohol, khat, tobacco and drug use. In addition, consanguinity, antenatal care (ANC) follow-up, and iron and folic acid supplementation data were included. From the ultrasound reading, gestational age of the fetus at diagnosis, number and sex of conceived fetuses, and anomalies associated with anencephaly were recorded. Pregnant women who were seriously ill and refusers were excluded from the study. The data were collected by a midwife and the ultrasound findings were interpreted by an experienced radiologist.

\section{Statistical Data Analysis}

All findings were coded and entered into Epi Info 7 and analyzed by SPSS version 20. Descriptive statistics were used to explain the study population in relation to the relevant variables. Binary logistic regression was carried out to check the associations between the dependent variable and each variable independently. The rejection level of significance for the univariate analysis was 0.2. Therefore, those factors with a $p$-value under 0.2 were entered into the multivariable analysis. Variables with a $p$-value less than 0.05 were taken as statistically significant in the multivariate logistic regression. The odds ratio (OR) with its $95 \%$ confidence interval (CI) was used to show the strength of association. The results are presented in the text, tables and figures.

\section{Results}

During a period of one year (February 2019 to January 2020), a total of 12,713 pregnant women visited the ultrasound center of EFGA Clinics. Forty-two pregnant women were diagnosed as carrying an anencephalic fetus, by obstetric ultrasound. Eighty-four pregnant women were taken as controls. However, one case and two controls had incomplete sociodemographic data, so they were excluded from the analysis. Therefore, based on this finding, the incidence of anencephaly was $3.3 / 1000$ pregnancies. The mean gestational age at diagnosis was 22 weeks.

The values for the different sociodemographic characteristics of the cases and controls were, respectively: $39 \%$ and 
$45.1 \%$ in the age range of $21-25$ years, $36.6 \%$ and $45.1 \%$ completed high school education, $87.8 \%$ and $93.9 \%$ Amhara ethnicity, and $73.8 \%$ and $78 \%$ lived in an urban location. Of the affected fetuses, $39 \%$ and $61 \%$ were male and female, respectively, while $51.8 \%$ and $48.2 \%$ of the control fetuses were male and female, respectively (Table 1).

Additional anomalies/conditions were detected in 29.3\% of the fetuses with anencephaly. Among these, 14.6\% were spina bifida, which is significant compared to the control fetuses ( $p=0.0001$ ), while $4.9 \%$ and $9.8 \%$ were oligohydramnios and polyhydramnios, respectively (Figure 1).

In univariate model analysis, maternal educational background, ethnicity, residence, occupation, ANC followup, folic acid supplementation during pregnancy and consanguinity (blood relationship between the fetus's father and mother) were not significantly associated with occurrence of anencephaly as a risk factor (Tables 1 and 2).

The multivariate logistic regression model indicated that maternal age between 26 and 30 years and khat chewing during pregnancy were significantly related to anencephaly (OR $0.13,95 \%$ CI $0.02-0.97, p=0.046$; and OR $3.571,95 \%$ CI $1.06-12.06, p=0.04$, respectively) (Table 3).

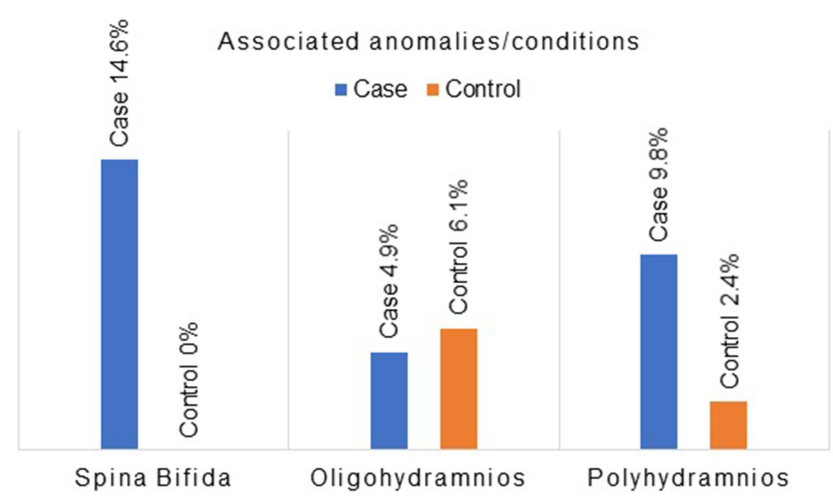

Figure I Anomalies/conditions associated with anencephalic and control fetuses.

In the association between anencephaly and disease and drug exposure during pregnancy, the presence of typhus and typhoid and drugs used for hypertension were significantly associated with the occurrence of anencephaly $(p<0.05)$ (Table 4).

\section{Discussion}

Anencephaly may be caused by the defective formation or absence of the cranium. Chronic exposure to amniotic fluid and certain mechanical traumas later induce

Table I Univariate Model Analysis of the Association Between Sociodemographic Factors and Occurrence of Anencephaly (Cases $n=4$ I, Controls $n=82$ )

\begin{tabular}{|c|c|c|c|c|c|c|}
\hline \multicolumn{2}{|l|}{ Variables } & \multicolumn{2}{|c|}{ Frequency, No (\%) } & \multirow{2}{*}{$\begin{array}{l}\text { COR } \\
0.222\end{array}$} & \multirow{2}{*}{$\begin{array}{c}95 \% \mathrm{Cl} \\
0.02-2.45 \mathrm{I}\end{array}$} & \multirow{2}{*}{$\begin{array}{r}p \text {-Value } \\
0.219\end{array}$} \\
\hline & & \multirow{2}{*}{$\begin{array}{c}\text { Controls } \\
3(3.7) \\
37(45.1) \\
29(35.4) \\
11(13.4) \\
2(2.4)\end{array}$} & \multirow{2}{*}{$\begin{array}{c}\text { Cases } \\
2(4.9) \\
16(39) \\
11(26.8) \\
6(14.6) \\
6(14.6)\end{array}$} & & & \\
\hline Maternal age (years) & $\begin{array}{c}\leq 20 \\
21-25 \\
26-30 \\
31-35 \\
>35\end{array}$ & & & $\begin{array}{c}0.222 \\
0.144 \\
0.126 \\
0.182 \\
\text { Ref }\end{array}$ & $\begin{array}{l}0.02-2.451 \\
0.026-0.792 \\
0.022-0.723 \\
0.028-1.197\end{array}$ & $\begin{array}{c}0.219 \\
0.026 \\
0.02 \\
0.076\end{array}$ \\
\hline Educational background & $\begin{array}{c}\text { No formal education } \\
\text { Elementary (grade I-8) } \\
\text { High school (grade 9-12) } \\
\text { College and above }\end{array}$ & $\begin{array}{c}4(4.9) \\
21(25.6) \\
37(45.1) \\
20(24.4)\end{array}$ & $\begin{array}{c}4(9.8) \\
12(29.3) \\
15(36.6) \\
10(24.4)\end{array}$ & $\begin{array}{c}2 \\
1.143 \\
0.81 \mathrm{I} \\
\operatorname{Ref}\end{array}$ & $\begin{array}{l}0.412-9.712 \\
0.404-3.230 \\
0.308-2.134\end{array}$ & $\begin{array}{c}0.39 \\
0.81 \\
0.671\end{array}$ \\
\hline Ethnicity & $\begin{array}{c}\text { Amhara } \\
\text { Oromo } \\
\text { Tigre }\end{array}$ & $\begin{array}{c}77(93.9) \\
3(3.7) \\
2(2.4)\end{array}$ & $\begin{array}{c}36(87.8) \\
2(4.9) \\
3(7.3)\end{array}$ & $\begin{array}{c}0.312 \\
0.444 \\
\text { Ref }\end{array}$ & $\begin{array}{c}0.05-1.948 \\
0.035-5.581\end{array}$ & $\begin{array}{l}0.212 \\
0.53\end{array}$ \\
\hline Residence & $\begin{array}{l}\text { Urban } \\
\text { Rural }\end{array}$ & $\begin{array}{l}64(78) \\
18(22)\end{array}$ & $\begin{array}{l}30(73.2) \\
\text { II (26.8) }\end{array}$ & $\begin{array}{c}0.767 \\
\text { Ref }\end{array}$ & $0.323-1.824$ & 0.549 \\
\hline Occupation & $\begin{array}{c}\text { Factory worker } \\
\text { Non-factory worker }\end{array}$ & $\begin{array}{c}5(6.1) \\
77(93.9)\end{array}$ & $\begin{array}{c}6(14.6) \\
35(85.4)\end{array}$ & $\begin{array}{c}2.64 \\
\text { Ref }\end{array}$ & $0.755-9.235$ & 0.129 \\
\hline Sex of the fetus & $\begin{array}{c}\text { Male } \\
\text { Female }\end{array}$ & $\begin{array}{l}42(51.2) \\
40(48.8)\end{array}$ & $\begin{array}{l}16(39) \\
25(61)\end{array}$ & $\begin{array}{l}0.6 \\
\text { Ref }\end{array}$ & $0.28-|.3|$ & 0.203 \\
\hline
\end{tabular}

Abbreviations: $\mathrm{COR}$, crude odds ratio; $\mathrm{Cl}$, confidence interval; Ref, reference. 
Table 2 Univariate Model Analysis of the Association Between Risk Factors and Occurrence of Anencephaly (Cases $n=4 I$, Controls $\mathrm{n}=82$ )

\begin{tabular}{|c|c|c|c|c|c|c|}
\hline \multicolumn{2}{|l|}{ Variables } & \multicolumn{2}{|c|}{ Frequency, No (\%) } & \multirow{3}{*}{$\begin{array}{c}\text { COR } \\
\begin{array}{c}2.025 \\
\text { Ref }\end{array}\end{array}$} & \multirow{3}{*}{$\begin{array}{c}95 \% \mathrm{Cl} \\
0.75-5.46\end{array}$} & \multirow{3}{*}{$\begin{array}{r}p \text {-Value } \\
0.163\end{array}$} \\
\hline & & \multirow{2}{*}{$\begin{array}{c}\text { Controls } \\
10(12.2) \\
72(87.8)\end{array}$} & \multirow{2}{*}{$\begin{array}{c}\text { Cases } \\
9(22) \\
32(78)\end{array}$} & & & \\
\hline $\begin{array}{l}\text { Any alcohol intake during } \\
\text { pregnancy }\end{array}$ & $\begin{array}{l}\text { Yes } \\
\text { No }\end{array}$ & & & & & \\
\hline Any khat chewing during pregnancy & $\begin{array}{l}\text { Yes } \\
\text { No }\end{array}$ & $\begin{array}{c}8(9.8) \\
74(90.2)\end{array}$ & $\begin{array}{l}9(22) \\
32(78)\end{array}$ & $\begin{array}{c}2.602 \\
\text { Ref }\end{array}$ & $0.92-7.35$ & 0.071 \\
\hline ANC follow-up & $\begin{array}{l}\text { Yes } \\
\text { No }\end{array}$ & $\begin{array}{l}73(89) \\
9(11)\end{array}$ & $\begin{array}{c}38(92.7) \\
3(7.3)\end{array}$ & $\begin{array}{c}\mathrm{I} .562 \\
\text { Ref }\end{array}$ & $0.39-6.11$ & 0.522 \\
\hline $\begin{array}{l}\text { Iron and folic acid supplementation } \\
\text { during pregnancy }\end{array}$ & $\begin{array}{l}\text { Yes } \\
\text { No }\end{array}$ & $\begin{array}{l}57(69.5) \\
25(30.5)\end{array}$ & $\begin{array}{l}28(68.3) \\
13(31.7)\end{array}$ & $\begin{array}{c}0.945 \\
\text { Ref }\end{array}$ & $0.42-2.12$ & 0.89 \\
\hline Consanguinity & $\begin{array}{l}\text { Yes } \\
\text { No }\end{array}$ & $\begin{array}{c}2(2.4) \\
80(97.6)\end{array}$ & $\begin{array}{c}2(4.9) \\
39(95.1)\end{array}$ & $\begin{array}{c}2.05 I \\
\text { Ref }\end{array}$ & $0.28-15.11$ & $0.48 I$ \\
\hline $\begin{array}{l}\text { Presence of any disease during } \\
\text { pregnancy }\end{array}$ & $\begin{array}{l}\text { Yes } \\
\text { No }\end{array}$ & $\begin{array}{l}\text { II (I3.4) } \\
71(86.6)\end{array}$ & $\begin{array}{l}14(34.1) \\
27(65.9)\end{array}$ & $\begin{array}{c}3.347 \\
\text { Ref }\end{array}$ & $1.35-8.28$ & 0.009 \\
\hline Any drug intake during pregnancy & $\begin{array}{l}\text { Yes } \\
\text { No }\end{array}$ & $\begin{array}{l}10(12.2) \\
72(87.8)\end{array}$ & $\begin{array}{l}14(34.1) \\
27(65.9)\end{array}$ & $\begin{array}{c}3.733 \\
\text { Ref }\end{array}$ & $|.48-9.4|$ & 0.005 \\
\hline
\end{tabular}

Abbreviations: COR, crude odds ratio; $\mathrm{Cl}$, confidence interval; Ref, reference.

Table 3 Multivariate Analysis of the Association Between Risk Factors and Occurrence of Anencephaly (Cases n=4I, Controls n=82)

\begin{tabular}{|c|c|c|c|c|c|c|}
\hline \multicolumn{2}{|l|}{ Variables } & \multicolumn{2}{|c|}{ Frequency, No (\%) } & \multirow[t]{2}{*}{ AOR } & \multirow[t]{2}{*}{$95 \% \mathrm{Cl}$} & \multirow[t]{2}{*}{$p$-Value } \\
\hline & & Controls & Cases & & & \\
\hline \multirow[t]{5}{*}{ Maternal age (years) } & $\leq 20$ & $3(3.7)$ & $2(4.9)$ & 0.204 & $0.01-3.09$ & 0.252 \\
\hline & $21-25$ & $37(45.1)$ & $16(39)$ & 0.244 & $0.04-1.69$ & 0.153 \\
\hline & $26-30$ & $29(35.4)$ & II (26.8) & 0.13 & $0.02-0.97$ & $0.046^{*}$ \\
\hline & $31-35$ & II (I3.4) & $6(14.6)$ & 0.148 & $0.02-1.32$ & 0.087 \\
\hline & $>35$ & $2(2.4)$ & $6(14.6)$ & Ref & & \\
\hline \multirow[t]{2}{*}{ Maternal occupation } & Factory worker & $5(6.1)$ & $6(14.6)$ & 0.447 & $1.88-0.37$ & 0.431 \\
\hline & Non-factory worker & 77 (93.9) & $35(85.4)$ & Ref & & \\
\hline \multirow[t]{2}{*}{ Sex of the fetus } & Male & $42(5 \mid .2)$ & $16(39)$ & 0.588 & $0.25-1.39$ & 0.229 \\
\hline & Female & $40(48.8)$ & $25(6 \mathrm{l})$ & Ref & & \\
\hline \multirow[t]{2}{*}{ Any alcohol intake during pregnancy } & Yes & $10(12.2)$ & $9(22)$ & 2.015 & $0.62-6.55$ & 0.244 \\
\hline & No & $72(87.8)$ & $32(78)$ & Ref & & \\
\hline \multirow[t]{2}{*}{ Any khat chewing during pregnancy } & Yes & $8(9.8)$ & $9(22)$ & 3.571 & $1.06-12.06$ & $0.04 *$ \\
\hline & No & $74(90.2)$ & $32(78)$ & Ref & & \\
\hline \multirow[t]{2}{*}{ Presence of any disease during pregnancy } & Yes & II (I3.4) & $14(34.1)$ & 1.032 & $0.13-8.39$ & 0.976 \\
\hline & No & $71(86.6)$ & $27(65.9)$ & Ref & & \\
\hline \multirow[t]{2}{*}{ Any drug intake during pregnancy } & Yes & $10(12.2)$ & $14(34.1)$ & 5.113 & $0.55-48.01$ & 0.153 \\
\hline & No & $72(87.8)$ & $27(65.9)$ & Ref & & \\
\hline
\end{tabular}

Note: *Significant $p$-value.

Abbreviations: AOR, adjusted odds ratio; $\mathrm{Cl}$, confidence interval; Ref, reference. 
Table 4 Association Between Anencephaly and Exposure to Risk Factors During Pregnancy (Cases $n=4 \mathrm{I}, \mathrm{Controls} \mathrm{n}=82$ )

\begin{tabular}{|c|c|c|c|c|c|c|c|}
\hline \multicolumn{3}{|l|}{ Variables } & \multicolumn{2}{|c|}{ Frequency, No (\%) } & \multirow{3}{*}{$\begin{array}{l}\text { COR } \\
16.68\end{array}$} & \multirow{3}{*}{$\begin{array}{c}95 \% \mathrm{Cl} \\
1.98-140.78\end{array}$} & \multirow{3}{*}{$\begin{array}{c}p \text {-Value } \\
0.01\end{array}$} \\
\hline & & & \multirow{2}{*}{$\begin{array}{c}\text { Controls } \\
\text { I (I.2) }\end{array}$} & \multirow{2}{*}{$\begin{array}{l}\text { Cases } \\
7(6.5)\end{array}$} & & & \\
\hline Disease exposure during pregnancy & Typhus and typhoid & Yes & & & & & \\
\hline & Hypertension & Yes & $2(2.4)$ & $4(9.8)$ & & & $\bullet$ \\
\hline & Asthma & Yes & $2(2.4)$ & 0 & & & $\bullet$ \\
\hline & Febrile illness & Yes & $\mathrm{I}(\mathrm{I} .2)$ & $3(7.3)$ & & & $\bullet$ \\
\hline & Gastritis & Yes & $3(3.7)$ & $\mathrm{I}(2.4)$ & & & $\bullet$ \\
\hline & UTI & Yes & $3(3.7)$ & 0 & & & $\bullet$ \\
\hline & STI & Yes & $\mathrm{I}(\mathrm{I} .2)$ & 0 & & & 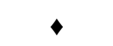 \\
\hline \multirow[t]{7}{*}{ Drugs used during pregnancy } & Antihypertensive drug & Yes & $\mathrm{I}(\mathrm{I} .2)$ & $4(9.8)$ & 10.67 & I.| $146-99.31$ & 0.038 \\
\hline & Drug for typhus and typhoid & Yes & 0 & $4(9.8)$ & & & $\bullet$ \\
\hline & Antiasthmatic & Yes & $2(2.4)$ & 0 & & & $\bullet$ \\
\hline & Drug for febrile illness & Yes & $\mathrm{I}(\mathrm{I} .2)$ & I (2.4) & & & $\bullet$ \\
\hline & Antiacid & Yes & $3(3.7)$ & I (2.4) & & & • \\
\hline & Antibiotic & Yes & $3(3.7)$ & $5(12.2)$ & & & $\bullet$ \\
\hline & Antifungal & Yes & I (I.2) & 0 & & & $\bullet$ \\
\hline
\end{tabular}

Note: $\diamond p$-Value $>0.05$ (not significant, so the corresponding COR and $\mathrm{Cl}$ are not reported for these variables).

Abbreviations: COR, crude odds ratio; Cl, confidence interval; UTI, urinary tract infection; STI, sexually transmitted infection.

degeneration and disorganization of the neuronal tissue, which is covered with an edematous and angiomatous membrane. ${ }^{18,19}$ Anencephaly can be diagnosed as early as 13 weeks of gestation using three-dimensional sonography. ${ }^{20,21}$

The incidence of anencephaly has been reported to show variation among different geographical regions. In this investigation, the incidence was 3.3/1000 pregnancies, which is slightly higher than the incidences reported in India, at 1.04 per 1000 births, ${ }^{9}$ and Gorgan, Iran, at 1.31 per 1000 births, $^{10}$ and lower than the incidence reported in Kashmir, which was 10.2/1000 pregnancies, as observed by ultrasound. ${ }^{7}$ The lower incidences reported in India may be due to early termination of diagnosed fetuses, which reduces the prevalence at birth, and changes in the level of ANC.

On the other hand, a study conducted in Addis Ababa, Ethiopia, reported a higher prevalence of anencephaly (63.4 per 10,000 births) than this research. This may be due to the study settings, as that study was conducted in referral hospitals, in which many cases are sent for further diagnosis and management. ${ }^{16}$

It has been reported that anencephaly occurs more frequently in female than in male fetuses. ${ }^{9,22,23}$ Although not statistically significant, in the present study, $61 \%$ of the affected fetuses were females. The reason for a female predominance is not known, and may need further investigation.
Many investigators have reported the protective effect of folic acid supplementation in the early first trimester of pregnancy. ${ }^{24-26}$ Even though not significant, in this study folic acid supplementation during early pregnancy showed a protective effect against the development of anencephaly. This may be due to there being nearly equal numbers of pregnant women $(31.7 \%$ and $30.5 \%$ of the cases and controls, respectively) who did not take folic acid. Such a finding was also reported by Li et al. ${ }^{27}$

The present study found that khat chewing during pregnancy was significantly associated with having an anencephalic fetus. With the current trend of an increase in the habit of consumption of khat in the study area, it would be interesting to investigate this further, considering dose, duration and time of khat chewing, and its effect on pregnancy. In line with this, previous studies have shown that chronic khat chewing affects the nervous system. It results in cognitive defects and psychosis associated with severe neurological illness, including abnormalities of the white matter and cortical atrophy of cerebral hemispheres, ${ }^{28}$ reduced brain weight, ${ }^{29}$ degeneration and necrosis of neurons and support cells of the brain, ${ }^{30}$ distorted cytoarchitecture of the prefrontal cortex, and impaired selective attention and working memory accuracy. ${ }^{31}$ Khat contains several psychoactive components, including cathinone, cathine, cathidine and norephedrine. $^{32}$ Such compounds may affect the development of the nervous system and be the reason for the present finding of khat as a risk factor for anencephaly. 
In the current investigation, maternal age between 26 and 30 years was significantly associated with the occurrence of anencephaly, although previous studies, by Aguiar et al and Barry Borman et al, reported no association between anencephaly and maternal age..$^{33,34}$ The observed higher incidence of anencephaly in mothers aged between 26 and 30 is comparable to that reported by Berihu et al for mothers in all age ranges. ${ }^{15}$ Nevertheless, the relatively high incidence of anencephaly observed in this study in mothers in the age group of 20 30 years is interesting and deserves further investigation.

Maternal exposure to hyperthermia around the time of anterior neuropore closure is significantly related to anencephaly. ${ }^{35}$ This is also in line with the current finding in which exposure of typhus and typhoid during early pregnancy significantly correlated with this anomaly. Furthermore, the present study found a significant correlation between anencephaly and the use of antihypertensive drugs during pregnancy $(p=0.038)$. On the other hand, in research conducted in Tigray and Addis Ababa, Ethiopia, the use of herbal medicines or drugs during pregnancy was not significantly associated with anencephaly. ${ }^{15,16}$ Such variation may be due to differences in the disease status of pregnant women and the time of initiating drug therapy for hypertension.

With respect to occupational hazards as a risk factor for anencephaly, no association was found in this study for mothers working in industry. However, a previous study reported that working in industry increases the risk of having a baby with anencephaly by up to 6.5 times compared with professional and businesswomen. ${ }^{36}$ In addition, the same study reported that low educational status is associated with a higher risk of giving birth to an infant with anencephaly, ${ }^{36}$ although this association was not found in the current study. The lack of a significant association with occupational hazards in the present study may be due to the low number of participants working in factories.

The existence of additional abnormalities with anencephaly has been reported by several investigators. Spina bifida is the anomaly most commonly associated with anencephaly. ${ }^{9,23}$ In the present study, spina bifida was also significantly associated with anencephaly $(p<0.0001)$. The simultaneous presence of anencephaly and spina bifida appears to be due to a common structural abnormality of the neural tube, as suggested by Barry Borman et al. ${ }^{34}$ Although not statistically significant, polyhydramnios and oligohydramnios were also detected with anencephaly.

\section{Conclusion}

The incidence of anencephaly in this study is almost within the range of many reports by different investigators in different regions, although it appears higher than the incidence in developed nations. Spina bifida, polyhydramnios and oligohydramnios appear to co-occur with anencephaly. Among several possible risk factors investigated in this study, exposure to typhus and typhoid during early pregnancy, taking drugs for hypertension, maternal age between 26 and 30 years, and khat chewing during pregnancy were found to be associated with anencephaly. Therefore, risk factors such as khat chewing during the gestational period may predispose to the development of anencephaly and should be discouraged. Further and particular investigations on risk factors such as khat chewing and their association with anencephaly should be conducted. Interpretation of these findings should be made with caution, since this study was conducted in a specific population and with limitations. The number of controls was limited and they were selected immediately following the confirmation of cases.

\section{Abbreviations}

ANC, antenatal care; AOR, adjusted odds ratio; CI, confidence interval; COR, crude odds ratio; EFGA, Ethiopian Family Guidance Association; OR, odds ratio; PCSK9, proprotein convertase subtilisin/kexin type 9 .

\section{Data Sharing Statement}

All data are included in the manuscript.

\section{Ethical Approval and Informed Consent}

The entire study protocol, including verbal informed consent, was approved by the ethical review board of Wollo University and the EFGA Clinic. This study was carried out in accordance with the Declaration of Helsinki. Informed verbal consent was also obtained from the participant mothers. All data collection tools were used anonymously to maintain confidentiality of data. Participation in the study was on a fully voluntary basis.

\section{Acknowledgments}

We extend our gratitude to the staff of Ethiopian Family Guidance Association Dessie Clinics for their support in data collection. We also thank the participant pregnant women who volunteered to take part in the study. 


\section{Author Contributions}

All authors made a significant contribution to the work reported, whether that is in the conception, study design, execution, acquisition of data, analysis and interpretation, or in all these areas; took part in drafting, revising or critically reviewing the article; gave final approval of the version to be published; have agreed on the journal to which the article has been submitted; and agree to be accountable for all aspects of the work.

\section{Disclosure}

All authors declare that they have no conflicts of interest.

\section{References}

1. Obeidi N, Russell N, Higgins JR, O'Donoghue K. The natural history of anencephaly. Prenat Diagn. 2010;30(4):357-360. doi:10.1002/ pd. 2490

2. Cook RJ, Erdman JN, Hevia M, Dickens BM. Prenatal management of anencephaly. Int $J$ Gynaecol Obstet. 2008;102(3):304-308. doi:10.1016/j.ijgo.2008.05.002

3. Yan L, Zhao L, Long Y, et al. Association of the maternal MTHFR C677T polymorphism with susceptibility to neural tube defects in offsprings: evidence from 25 case-control studies. PLoS One. 2012;7 (10):e41689. doi:10.1371/journal.pone.0041689

4. Finnell RH, Gould A, Spiegelstein O. Pathobiology and genetics of neural tube defects. Epilepsia. 2003;44:14-23. doi:10.1046/j.15281157.44.s3.5.x

5. Pulikkunnel ST, Thomas S. Neural tube defects: pathogenesis and folate metabolism. J Assoc Physicians India. 2005;53:127-135.

6. Erol SA, Tanacan A, Firat Oguz E, et al. A comparison of the maternal levels of serum proprotein convertase subtilisin/kexin type 9 (PCSK9) in pregnant women with the complication of fetal open neural tube defects. Congenit Anom. 2021;61(5):169-176. doi:10. 1111/cga.12432

7. Akhtar M, Qaiser Q, Latif A. Antenatal diagnosis of anencephaly to determine the prevalence and its correlation with folic acid deficiency by using peripheral blood picture in District Poonch, Azad Kashmir. Methods. 2016;10(2):1-3.

8. Jaquier M, Klein A, Boltshauser E. Spontaneous pregnancy outcome after prenatal diagnosis of anencephaly. BJOG. 2006;113(8): 951-953. doi:10.1111/j.1471-0528.2006.01014.x

9. Shilpa K, Ranganath P, Sumathi S. Frequency of anencephaly and its associated anomalies. Int $J$ Anat Res. 2018;6(2.3):5294-5300. doi:10.16965/ijar.2018.190

10. Golalipour MJ, Najafi L, Keshtkar AA. Prevalence of anencephaly in Gorgan, northern Iran. Arch Iran Med. 2010;13(1):34-37.

11. Loncarek K, Mustac E, Frkovic A, Prodan M. Prevalence of anencephaly in the region of Rijeka, Croatia. Eur J Epidemiol. 2001;17 (3):241-244. doi:10.1023/A:1017981815982

12. Tan K, Tan S, Tan K, Yeo G. Anencephaly in Singapore: a ten-year series from 1993-2002. Singapore Med J. 2007;48(1):12-15.

13. Mahadevan B, Bhat BV. Neural tube defects in Pondicherry. Indian J Pediatr. 2005;72(7):557-559. doi:10.1007/BF02724177

14. Sood M, Agarwal N, Verma S, Bhargava S. Neural tubal defects in an east Delhi hospital. Indian J Pediatr. 1991;58(3):363-365. doi:10. 1007/BF02754968

15. Berihu BA, Welderufael AL, Berhe Y, et al. Maternal risk factors associated with neural tube defects in Tigray regional state of Ethiopia. Brain Dev. 2019;41(1):11-18. doi:10.1016/j.braindev.20 18.07.013
16. Gedefaw A, Teklu S, Tadesse BT. Magnitude of neural tube defects and associated risk factors at three teaching hospitals in Addis Ababa, Ethiopia. Biomed Res Int. 2018;2018:1-10.

17. Murshid WR, Jarallah JS, Dad MI. Epidemiology of infantile hydrocephalus in Saudi Arabia: birth prevalence and associated factors. Pediatr Neurosurg. 2000;32(3):119-123. doi:10.1159/ 000028915

18. Bacha R, Gilani S, Manzoor I. Sonographic transformation of acrania to anencephaly. Donald School J Ultrasound Obstet Gynecol. 2017;11(3):1-8.

19. Chen CP. First trimester sonographic demonstration of a mobile cranial cyst associated with anencephaly and amniotic band sequence. Ultrasound Obstet Gynecol. 2001;17(4):360-361. doi:10.1046/j.1469-0705.2001.00389.x

20. Hata T, Hanaoka U, Tenkumo C, Sato M, Tanaka H, Ishimura M. Three-and four-dimensional HDlive rendering images of normal and abnormal fetuses: pictorial essay. Arch Gynecol Obstet. 2012;286 (6):1431-1435. doi:10.1007/s00404-012-2505-1

21. Hata T, Uketa E, Tenkumo C, Hanaoka U, Kanenishi K, Tanaka H. Three-and four-dimensional HDlive rendering image of fetal acrania/ exencephaly in early pregnancy. $J$ Med Ultrasonics. 2013;40 (3):271-273. doi:10.1007/s10396-012-0420-5

22. Hassan M, Muhammad N, Gul F, et al. Frequency of anencephaly in Hazara Division of Pakistan. Am J Drug Deliv Therap. 2015;2 (1):39-43.

23. Waghmode GT, Salve VM, Gosavi AG. Prevalence of anencephaly associated anomalies. Indian J Clin Anat Physiol. 2018;5 (1):25-28.

24. Centers for Disease Control and Prevention. Spina bifida and anencephaly before and after folic acid mandate-United States, 19951996 and 1999-2000. MMWR Morb Mortal Wkly Rep. 2004;53 (17):362-365.

25. Klusmann A, Heinrich B, Stopler H, Gartner J, Mayatepek E, Von Kries R. A decreasing rate of neural tube defects following the recommendations for periconceptional folic acid supplementation. Acta Paediatr. 2005;94(11):1538-1542. doi:10.1080/0803525050 0340396

26. Parker SE, Mai CT, Canfield MA, et al. Updated national birth prevalence estimates for selected birth defects in the United States, 2004-2006. Birth Defects Res A Clin Mol Teratol. 2010;88 (12):1008-1016. doi:10.1002/bdra.20735

27. Li Z, Ren A, Zhang L, Guo Z, Li Z. A population-based casecontrol study of risk factors for neural tube defects in four highprevalence areas of Shanxi province, China. Paediatr Perinat Epidemiol. 2006;20(1):43-53. doi:10.1111/j.1365-3016.2006.00 694.x

28. Morrish P, Nicolaou N, Brakkenberg P, Smith P. Leukoencephalopathy associated with khat misuse. $J$ Neurol Neurosurg Psychiatry. 1999;67(4):556. doi:10.1136/jnnp.67.4.556

29. Muche A, Makonnen E, Kinfu Y, Afework M. The effect of ethanol and khat (Catha edulis Forsk) on the cerebellar cortex of early postnatal rats. Pharmacologyonline. 2006;3:862-876.

30. Abdul-Mughni AS, El-Nahla SM, Hassan SA, Dessouki AA. Teratogenic effects of Khat (Catha edulis) in New Zealand rabbit. J Adv Vet Anim Res. 2018;5(1):25-36. doi:10.5455/javar. 2018.e242

31. Echoru I, Bukenya EE, Masilili G, Owembabazi E, Lemuel AM, Ahimbisibwe J. Khat distorts the prefrontal cortex histology and function of adult Wistar rats. Anat J Afr. 2018;7(1):1121-1131. doi:10.4314/aja.v7i1.169485

32. Kalix P. Pharmacological properties of the stimulant khat. Pharmacol Ther. 1990;48(3):397-416. doi:10.1016/0163-7258(90) 90057-9

33. Aguiar MJ, Campos ÃS, Aguiar RA, Lana AMA, Magalhães RL, Babeto LT. Neural tube defects and associated factors among liveborn and stillborn infants. J Pediatr. 2003;79(2):129-134. 
34. Barry Borman G, Smith AH, Keir Howard J. Risk factors in the prevalence of anencephalus and spina bifida in New Zealand. Teratology. 1986;33(2):221-230. doi:10.1002/tera.1420330209

35. Miller P, Smith D, Shepard T. Maternal hyperthermia as a possible cause of anencephaly. Lancet. 1978;311(8063):519-521. doi:10.1016/ S0140-6736(78)90549-4
36. Muñoz JB, Lacasaña M, Aburto VHB, Sánchez LET, García AMG, Carrillo LL. Socioeconomic factors and the risk of anencephaly in a Mexican population: a case-control study. Public Health Rep. 2005;120(1):39-45. doi:10.1177/003335490512000108

\section{Publish your work in this journal}

Pediatric Health, Medicine and Therapeutics is an international, peerreviewed, open access journal publishing original research, reports, editorials, reviews and commentaries. All aspects of health maintenance, preventative measures and disease treatment interventions are addressed within the journal. Practitioners from all disciplines are invited to submit their work as well as healthcare researchers and patient support groups. The manuscript management system is completely online and includes a very quick and fair peer-review system. Visit http://www.dovepress.com/testimonials.php to read real quotes from published authors. 